\title{
Do age and feeding levels have comparable effects on fat deposition in breast muscle of mule ducks?
}

\author{
P. Chartrin ${ }^{1 \dagger}$, M. D. Bernadet ${ }^{2}$, G. Guy ${ }^{2}$, J. Mourot ${ }^{3}$, J.-F. Hocquette ${ }^{4}$, N. Rideau' ${ }^{1}$, M.-J. Duclos ${ }^{1}$ \\ and E. Baéza ${ }^{1}$

\footnotetext{
${ }^{1}$ Station de Recherches Avicoles, INRA Tours, 37380 Nouzilly, France; ${ }^{2}$ Unité Expérimentale sur les Palmipèdes à Foie Gras, INRA Artiguères, 40280 Benquet, France; ${ }^{3}$ Unité Systèmes d'Elevage Nutrition Animale et Humaine, INRA, 35590 St Gilles, France; ${ }^{4}$ Unité de Recherches sur les Herbivores, INRA Theix, 63122 St Genès Champanelle, France
}

(Received 15 June 2006; Accepted 7 September 2006)

The effects of age (from 1 day post-hatch to 98 days of age) and feeding levels (feed restriction followed by overfeeding $v$. ad libitum feeding) on lipid deposition in breast muscle (quantity and quality, localisation) of mule ducks were determined in relation to muscle energy metabolism (glycolytic and oxidative), plasma levels of lipids, glucose and insulin, and muscle capacity for lipid uptake (characterised by lipoprotein lipase (LPL) activity). Two periods were defined for age effects on intramuscular lipids in breast muscle: -1 to 42 days of age when lipids (mainly phospholipids and cholesterol provided by egg yolk) stored in the adipocytes during embryonic life were transferred to the muscle fibres and used for growth and energy requirements, -42 to 98 days of age when the muscle again stored lipids (mainly triglycerides provided by liver lipogenesis), first in fibres and then in adipocytes.

Plasma glucose and insulin levels were not affected by age. Plasma levels of lipids and LPL activity in breast muscle were high at 1 and 14 days of age and then decreased, remaining stable until 98 days of age. Energy metabolism activity in the breast muscle (mainly glycolytic activity) increased with age.

Feed restriction, corresponding to $79 \%$ of ad libitum intake, applied between 42 and 75 days of age only resulted in decreases in plasma insulin concentration and total lipid content of breast muscle, mainly affecting triglyceride and mono-unsaturated fatty acid (MUFA) levels. Overfeeding increased plasma levels of insulin and lipids while glycaemia remained stable. LPL activity and total lipid levels increased in breast muscle, mainly induced by deposition of triglycerides and MUFA occurring particularly during the 2nd week of this period. Glycolytic energy metabolism decreased.

In response to age or feeding levels, muscle lipid levels and composition reflect plasma lipid levels and composition and high muscle lipid levels stimulate oxidative energy metabolism.

Keywords: age, breast muscle, ducks, feeding levels, lipids

\section{Introduction}

The effects of age on lipid levels in poultry muscle depend on the species. In chickens, lipid levels in breast and thigh muscles remain stable or decrease with age, at least until 100 days (Touraille et al., 1981; Hamm and Ang, 1984; Rabot, 1998) and then, according to the few reports available for older chickens, lipid levels possibly increase (Marion and Miller, 1968; Grey et al., 1983). Wangen et al. (1972) reported that lipid levels in the breast muscle remained unchanged in turkeys killed at intervals of 4 weeks from 4 to 28 weeks, whereas they increased in thigh muscle after

${ }^{\dagger}$ E-mail: chartrin@tours.inra.fr
16 weeks of age. Komprda et al. (2002) found significant increases in lipid levels in breast and thigh muscles of turkeys slaughtered at 1-week intervals between 10 and 25 weeks of age. In ducks, only Setiawan et al. (1994) and Baéza et al. (2000) and (2002) showed an increase in lipid content of breast muscle of mule and Muscovy ducks between $6-8$ and 12-13 weeks of age. Lipid content of muscle can also be manipulated by feeding levels, with feed restriction often decreasing intramuscular fat content and overfeeding inducing an increase. In particular, Auvergne (1992) showed that lipid levels in the breast meat of overfed ducks were 2.0-fold higher than in ducks fed ad libitum. In practice, the overfeeding period often lasts for 2 weeks and occurs after a period of feed restriction followed by 
a pre-overfeeding period. The aim of the feed restriction is to induce later a catch-up growth that may maximise the effects of overfeeding. During the pre-overfeeding period birds are trained to ingest increasing amounts of feed. The mule duck is the main species used to produce fatty liver.

It was therefore very interesting to study the effects of age on intramuscular lipid deposition in mule ducks usually reared for overfeeding, since this type of production also enabled us to study the effects of feeding levels. Both lipids and glucose represent energy sources for muscle metabolism, and their levels depend on circulating blood levels, and on the uptake and oxidation ability of muscles (Hocquette et al., 1998a). It is generally accepted that muscle oxidative metabolism is prevalent at the beginning of postnatal development and is progressively replaced by glycolytic metabolism, as described by Bacou and Vigneron (1976) in chicks, Briand et al. (1993) in rabbits and Baéza et al. (1998) in Muscovy ducks. These changes can be modified by feeding levels. For example, in one study, overfed ducks had higher $\beta$-hydroxyacyl CoA dehydrogenase (HAD) activity in breast muscles than ad libitum-fed ducks (Baéza et al., 2005). The aim of this study was therefore to determine the effects of age (from 1 day post hatching to 98 days of age) and feeding levels (feed restriction followed by overfeeding v. ad libitum feeding) on lipid deposition in breast muscle (quantity and quality, localisation) of mule ducks compared with muscle energy metabolism (glycolytic and oxidative), plasma levels of lipids, glucose and insulin, and muscle capacity for lipid uptake (characterised by lipoprotein lipase activity).

\section{Material and methods}

\section{Animals and experimental design}

We used 140 male mule ducks provided by Grimaud (Roussay, France). The birds were distributed into two groups and reared under the usual conditions of light and temperature at the Experimental Station for Waterfowl Breeding (INRA Artiguères, France). From hatching to 42 days of age, all ducks were fed ad libitum. From 42 to 76 days of age, the ducks of the restricted then overfed group (ROF) were fed restricted $(260 \mathrm{~g}$ of feed per duck per day between 43 and 68 days of age and $230 \mathrm{~g}$ of feed per duck per day between 69 and 76 days). Feed amounts were then progressively increased to reach $350 \mathrm{~g}$ at 83 days of age. At 84 days of age, ducks were overfed for 14 days with maize and maize meal $(329 \mathrm{~g}$ at 84 days to reach $1532 \mathrm{~g}$ at 97 days of age). From 42 to 97 days of age, ducks of the ad libitum-fed group (ALF) were fed ad libitum with the growing diet. The main characteristics of the diets (starting, growing and overfeeding) are shown in Table 1. The details of diet composition have already been presented by Chartrin et al. (2006). Feed consumption was recorded for each period per group.

At 1, 14, 42, 75, 84, 91 and 98 days of age, 10 ducks per group, deprived of feed overnight, were randomly selected and weighed. Blood samples were drawn by
Table 1 Main characteristics of feed for rearing and overfeeding periods. Preparation for overfeeding contained maize (25\%), maize meal (35\%) and water (40\%)

\begin{tabular}{lccc}
\hline \hline Characteristics $^{\dagger}$ & $\begin{array}{c}\text { Starting } \\
\text { (0-28 days) }\end{array}$ & $\begin{array}{c}\text { Growing } \\
(29-83 \text { days })\end{array}$ & $\begin{array}{c}\text { Overfeeding } \\
\text { (84-97 days) }\end{array}$ \\
\hline ME (kcal/kg) & 2830 & 2850 & 3330 \\
CP (\%) & 18.21 & 15.98 & 8.28 \\
Lipids (\%) & 3.34 & 2.84 & 3.38 \\
SFA (\%) & 17.17 & 16.10 & 14.52 \\
MUFA (\%) & 24.98 & 28.36 & 27.44 \\
PUFA (\%) & 57.85 & 55.54 & 58.02 \\
\hline \hline
\end{tabular}

${ }^{\dagger} \mathrm{ME}=$ metabolisable energy; $\mathrm{CP}=$ crude protein; SFA, MUFA, PUFA = saturated, mono-unsaturated and poly-unsatured fatty acids, respectively.

puncture of the occipital venous sinus, collected on EDTA $(1.2 \mathrm{~g} / \mathrm{l})$ in a vacuum tube and kept at $2-$ to $4^{\circ} \mathrm{C}$ during the subsequent procedure. Individual plasma samples were separated by centrifugation at $2000 \mathrm{~g}$ for $10 \mathrm{~min}$ at $4^{\circ} \mathrm{C}$. Plasma samples were then frozen at $-20^{\circ} \mathrm{C}$ until further analysis. Ducks were then sacrificed by cervical dislocation. Immediately after bleeding, the liver and breast muscle (pectoralis major) were excised and weighed. One sample of $p$. major was quickly frozen in isopentane, cooled with liquid nitrogen and stored at $-80^{\circ} \mathrm{C}$ until histochemical analysis was performed, as previously described by Baéza et al. (1999). A sample of the p. major muscle was quickly frozen in liquid nitrogen and stored at $-80^{\circ} \mathrm{C}$ prior to determination of enzymatic activity. A sample of the $p$. major muscle was also frozen and stored at $-20^{\circ} \mathrm{C}$ for chemical analysis.

The present study was carried out in accordance with the French legislation on animal experimentation and with the authorisation of the French Ministry of Agriculture (Animal Health and Protection Directorate).

\section{Histological analysis}

The levels of triglycerides (stained with red oil $=\mathrm{RO}$ ), and total lipid (stained with Sudan black $=S B$ ), were determined in muscle fibres according to type as previously described by Chartrin et al. (2005): fast-twitch fibres with glycolytic energy metabolism $(\alpha \mathrm{W})$ or oxydo-glycolytic energy metabolism $(\alpha R)$. Staining intensities were expressed as luminance (LC RO and LC SB), with luminance being negatively correlated with lipid and triglyceride contents. We also evaluated the relative surfaces occupied by adipocytes on cross-sectional areas of each muscle sample as described by Chartrin et al. (2005) and the results were expressed as the relative surface occupied by adipocyte cluster per observed field (\%).

\section{Blood analysis}

Plasma glucose levels were determined enzymatically using a Beckman autoanalyser and the corresponding kit (Kadish et al., 1968).

Plasma triglyceride (TG), total cholesterol (CT) and phospholipid (PL) levels were quantified by colorimetric enzymatic 
Lipid deposition in duck muscles

methods according to Fossati and Prencipe (1982), Richmond (1973) and Takayama et al. (1977), respectively, and using kits provided by Bio-Mérieux (Marcy-l'Etoile, France).

Plasma insulin levels were determined by radioimmunoassay as previously described by Simon et al. (1974). The lowest limit of sensitivity was $2 \mu \mathrm{U} / \mathrm{ml}$, and interassay variation was less than $10 \%$.

\section{Lipid analysis}

Total lipids were extracted from muscle, by homogenising samples of minced tissue in chloroform/methanol 2/1 (v/v) and collecting gravimetrically (Folch et al., 1957). Lipid classes were determined using an latroscan (latron, Tokyo, Japan) with 10 silica-gel thin layer chromatography rods and a flame ionisation detector system (TLC-FID) according to Mares et al. (1983). The hydrogen flow rate was $160 \mathrm{ml} /$ $\mathrm{min}$, the air flow rate $2 \mathrm{l} / \mathrm{min}$ and scanning speed $0.3 \mathrm{~cm} / \mathrm{s}$. The software used (Boreal, JMBS Development, Grenoble, France) recorded chromatograms and integrated peaks with reference to an external standard (Sigma, St Quentin Fallavier, France). Fatty acid composition was determined after transmethylation of lipids (Morrisson and Smith, 1964) by gas chromatography (Perkin Elmer Autosystem, St Quentin en Yvelines, France). Injector and detector (FID) temperatures were $250^{\circ} \mathrm{C}$, and the carrier gas was nitrogen with a head column pressure of 16.5 p.s.i. using a capillary column $(25 \mathrm{~m} \times 0.22 \mathrm{~mm}$, BPX70, SGE, Villeneuve St Georges, France). Methyl esters were identified and quantified by comparison with standards (Sigma, St Quentin Fallavier, France). Because of the small amounts of muscles at 1 and 14 days of age, analysis of lipids was performed with one pool of 20 muscles and two pools of 10 muscles, respectively.

\section{Determination of enzyme activity}

Lipoprotein lipase (LPL) activity was determined in the $p$. major muscle according to Hocquette et al. (1998b). The activity of the enzymes for glycolytic (lactate dehydrogenase, LDH) and oxidative ( $\beta$-hydroxyacyl CoA dehydrogenase, HAD and citrate synthase, CS) muscle energy metabolism was assayed in the p. major muscle (Bass et al., 1969).

\section{Statistical analysis}

Data were analysed by analysis of variance using the general linear model procedure of Statistical Analysis Systems Institute (1989). Age effects were only tested in the ALF group between 1 and 98 days of age, and the effects of feeding levels were tested at each slaughter age between 75 and 98 days. By taking into account the values for all ages and feeding levels, we calculated Pearson correlations between LPL activity and lipid levels in the breast muscle, or phospholipid, triglyceride and cholesterol levels in plasma.

\section{Results}

Growth performance

Feed consumption was similar in both groups between 1 and 42 days of age (Table 2). Feed restriction corresponded to $79 \%$ of ad libitum ingestion between 43 and 75 days of age. Ducks from the ROF group ingested $0.3 \mathrm{~kg}$ less than ducks from the ALF group during the pre-overfeeding period (Table 2). At 83 days of age, ad libitum-fed ducks had ingested about $2.5 \mathrm{~kg}$ more feed than restricted ducks, and between 84 and 97 days of age overfed ducks had ingested three times the amount of feed ingested by ad libitum-fed ducks (Table 2).

The greatest increases in body weight and liver weight occurred between 1 and 14 days of age (10- and 15-fold, respectively), whereas the greatest increases in weight of the $p$. major muscle occurred between 14 and 42 days of age (27-fold, Table 3). Body weight remained stable in ALF ducks after 84 days of age. Feed restriction exerted no significant effect on body weight or on weight of the p. major muscle but it increased liver weight $(+24 \%$ and $+14 \%$ at 75 and 84 days of age, respectively) and the relative weight of liver to body weight (1.66 v. $1.40 \%$ and $1.74 \mathrm{v}$. $1.48 \%$ at 75 and 84 days of age, respectively). Overfeeding induced a marked increase in body weight $(+12 \%$ and $+41 \%$ after 1 and 2 weeks, respectively) and liver weight (2.8-fold and 6.7-fold heavier after 1 and 2 weeks, respectively) while the weight of the $p$. major muscle decreased during the 1 st week of this period $(-12 \%)$. At the end of the overfeeding period ducks of both groups exhibited similar muscle weights (Table 3).

\section{Blood parameters}

Circulating glucose concentration increased between 1 and 14 days of age, then remained stable in the ALF group (Table 4). Neither feed restriction nor overfeeding significantly affected glycaemia levels (Table 4).

Plasma insulin levels remained stable until 75 days, and then significantly increased at 91 and 98 days in the ALF group (Table 4). Feed restriction resulted in a significant decrease $(-25 \%$ at 75 days of age) and 2 weeks of overfeeding resulted in a significant increase in plasma insulin level $(+67 \%$ at 98 days of age, Table 4$)$.

Plasma triglyceride levels first increased between 1 and 14 days then remained stable until 98 days, except for the lowest value measured at 91 days in the ALF group

Table 2 Cumulative feed consumption $(\mathrm{kg})$ per duck and per period for ad libitum-fed (ALF) group and restricted then overfed (ROF) group $(n=1)$

\begin{tabular}{lcr}
\hline \hline Periods & \multicolumn{1}{c}{ ROF } & \multicolumn{1}{c}{ ALF } \\
\hline $1-42$ days & 6.89 (ad libitum-fed) & 6.86 (ad libitum-fed) \\
$43-75$ days & 8.37 (restricted) & 10.60 (ad libitum-fed) \\
$76-83$ days & 2.23 (pre-overfed) & 2.53 (ad libitum-fed) \\
$84-97$ days & 10.09 (overfed) & 3.27 (ad libitum-fed) \\
\hline \hline
\end{tabular}


Chartrin, Bernadet, Guy, Mourot, Hocquette, Rideau, Duclos and Baéza

Table 3 Effects of age and feeding levels on body weight, and liver and breast muscle (p. major) weight of mule ducks (mean \pm s.e.)

\begin{tabular}{|c|c|c|c|c|}
\hline Age (days) & Feeding levels & Body weight (g) & P. major weight $(\mathrm{g})$ & Liver weight (g) \\
\hline $1(n=20)$ & Ad libitum-fed & $48 \pm 2^{f}$ & $0.31 \pm 0.03^{d}$ & $1.28 \pm 0.08^{\mathrm{e}}$ \\
\hline $14(n=20)$ & Ad libitum-fed & $474 \pm 54^{\mathrm{e}}$ & $2.47 \pm 0.38^{d}$ & $19.63 \pm 3.59^{d}$ \\
\hline $42(n=20)$ & Ad libitum-fed & $2871 \pm 122^{d}$ & $67.35 \pm 6.60^{c}$ & $52.51 \pm 3.91^{c}$ \\
\hline $75(n=10)$ & Ad libitum-fed & $3981 \pm 344^{c}$ & $252.54 \pm 15.40^{b}$ & $55.78 \pm 6.00^{c}$ \\
\hline $75(n=10)$ & Restricted & $4171 \pm 160$ & $265.47 \pm 13.63$ & $69.37 \pm 8.40^{*}$ \\
\hline $84(n=10)$ & Ad libitum-fed & $4543 \pm 344^{a}$ & $308.96 \pm 36.51^{\mathrm{a}}$ & $67.08 \pm 5.89^{a}$ \\
\hline $84(n=10)$ & Pre-overfed & $4407 \pm 277$ & $306.62 \pm 63.28$ & $76.71 \pm 9.59^{*}$ \\
\hline $91(n=10)$ & Ad libitum-fed & $4576 \pm 260^{a}$ & $310.65 \pm 21.06^{\mathrm{a}}$ & $59.63 \pm 5.36^{\mathrm{b}}$ \\
\hline $91(n=10)$ & Overfed & $5124 \pm 358^{*}$ & $272.36 \pm 22.47^{*}$ & $166.22 \pm 32.66^{*}$ \\
\hline $98(n=10)$ & Ad libitum-fed & $4334 \pm 360^{b}$ & $313.65 \pm 31.56^{\mathrm{a}}$ & $56.74 \pm 6.39^{b}$ \\
\hline $98(n=10)$ & Overfed & $6101 \pm 266^{*}$ & $304.21 \pm 52.34$ & $379.62 \pm 93.92 *$ \\
\hline
\end{tabular}

a-f Significant effect of age for ad libitum-fed group $(P<0.05)$.

${ }^{*}$ Significant effect of feeding levels for a given age (between 75 and 98 days) $(P<0.05)$.

(Table 4). Feed restriction had no significant effect, while overfeeding resulted in considerable increases in plasma triglyceride levels (3.7-fold and 5.1-fold at 91 and 98 days of age, respectively, Table 4).

Plasma phospholipid levels were high at 1 and 14 days of age (Table 4), then decreased and remained stable at around $3.2 \mathrm{mmol} / \mathrm{l}$ until the end of the experiment in the ALF group. Feed restriction had no significant effect, while overfeeding resulted in an increase in plasma phospholipid levels (1.3-fold and 1.6-fold at 91 and 98 days of age, respectively, Table 4 ).

Plasma cholesterol levels were high at 1 and 14 days of age (Table 4), then decreased and remained stable at around $4.34 \mathrm{mmol} / \mathrm{l}$ until the end of the experiment in the ALF group. Feed restriction had no significant effect, while overfeeding resulted in an increase in plasma cholesterol levels (1.4-fold and 1.6-fold at 91 and 98 days of age, respectively, Table 4 ).

Lipid composition of breast muscle

In the ALF group, muscle lipid content first decreased from 1 to 42 days of age $(-57 \%$, Table 5$)$, and then increased significantly between 42 and 75 days of age (2.2-fold) and between 91 and 98 days of age (1.3-fold). Feed restriction significantly decreased muscle lipid content $(-16 \%)$. Pre-overfeeding resulted in an increase in muscle lipid content, reaching similar levels to those observed in ad libitum-fed ducks at 84 days of age. Overfeeding resulted in an increase in muscle lipid content, particularly during the 2 nd week $(+12 \%$ and $+40 \%$ at 91 and 98 days of age, respectively, Table 5).

Muscle triglyceride content increased in the ALF group between 1 and 14 days of age $(+85 \%)$ then markedly decreased (value divided by 6.6 between 14 and 42 days of age, Table 5), but from 75 to 98 days of age it increased steadily $(+98 \%)$. Feed restriction decreased $(-31 \%)$ and overfeeding increased muscle triglyceride content, particularly during the 2nd week $(+22 \%$ and $+60 \%$ at 91 and 98 days of age, respectively, Table 5 ).

Muscle phospholipid content decreased in the ALF group between 1 and 14 days of age $(-39 \%$, Table 5$)$, then increased regularly until 98 days of age (1.7-fold). Feed restriction had no significant effect while overfeeding slightly increased muscle phospholipid content at 98 days of age $(+14 \%$, Table 5$)$.

Table 4 Effects of age and feeding levels on plasma levels of glucose, triglycerides, phospholipids, cholesterol and insulin of mule ducks. Plasma samples were collected following overnight fasting (means \pm s.e.)

\begin{tabular}{lllllcc}
\hline \hline Age (days) & Feeding levels & Glucose $(\mathrm{g} / \mathrm{l})$ & $\begin{array}{c}\text { Triglycerides } \\
(\mathrm{mmol} / \mathrm{l})\end{array}$ & $\begin{array}{c}\text { Phospholipids } \\
(\mathrm{mmol} / \mathrm{l})\end{array}$ & $\begin{array}{c}\text { Cholesterol } \\
(\mathrm{mmol} / \mathrm{l})\end{array}$ & $\begin{array}{c}\text { Insulin } \\
(\mu \mathrm{U} / \mathrm{ml})\end{array}$ \\
\hline $1(\mathrm{n}=20)$ & Ad libitum-fed & $1.95 \pm 0.14^{\mathrm{c}}$ & $0.50 \pm 0.20^{\mathrm{bc}}$ & $4.45 \pm 0.56^{\mathrm{b}}$ & $15.81 \pm 2.90^{\mathrm{a}}$ & $14.06 \pm 5.80^{\mathrm{ab}}$ \\
$14(\mathrm{n}=20)$ & Ad libitum-fed & $2.25 \pm 0.32^{\mathrm{ab}}$ & $0.72 \pm 0.22^{\mathrm{a}}$ & $5.04 \pm 1.03^{\mathrm{a}}$ & $7.86 \pm 1.40^{\mathrm{b}}$ & $14.95 \pm 8.07^{\mathrm{ab}}$ \\
$42(\mathrm{n}=20)$ & Ad libitum-fed & $2.38 \pm 0.30^{\mathrm{a}}$ & $0.65 \pm 0.13^{\mathrm{abc}}$ & $3.50 \pm 0.34^{\mathrm{c}}$ & $4.76 \pm 0.27^{\mathrm{c}}$ & $9.30 \pm 2.79^{\mathrm{b}}$ \\
$75(\mathrm{n}=10)$ & Ad libitum-fed & $2.18 \pm 0.26^{\mathrm{abc}}$ & $0.59 \pm 0.29^{\mathrm{abc}}$ & $3.30 \pm 0.43^{\mathrm{cd}}$ & $4.32 \pm 0.59^{\mathrm{c}}$ & $12.35 \pm 2.83^{\mathrm{ab}}$ \\
$75(\mathrm{n}=10)$ & Restricted & $2.09 \pm 0.31$ & $0.82 \pm 0.41$ & $3.38 \pm 0.45$ & $4.42 \pm 0.87$ & $9.30 \pm 3.75^{*}$ \\
$84(\mathrm{n}=10)$ & Ad libitum-fed & $2.14 \pm 0.31^{\mathrm{abc}}$ & $0.76 \pm 0.31^{\mathrm{a}}$ & $2.87 \pm 0.46^{\mathrm{d}}$ & $4.03 \pm 0.59^{\mathrm{c}}$ & $9.45 \pm 6.17^{\mathrm{b}}$ \\
$84(\mathrm{n}=10)$ & Pre-overfed & $2.21 \pm 0.31$ & $1.17 \pm 0.58$ & $2.93 \pm 0.59$ & $3.94 \pm 0.82$ & $13.65 \pm 3.13$ \\
$91(\mathrm{n}=10)$ & Ad libitum-fed & $2.00 \pm 0.32^{\mathrm{bc}}$ & $0.49 \pm 0.16^{\mathrm{c}}$ & $3.04 \pm 0.45^{\mathrm{cd}}$ & $4.47 \pm 0.56^{\mathrm{c}}$ & $18.50 \pm 13.96^{\mathrm{a}}$ \\
$91(\mathrm{n}=10)$ & Overfed & $2.09 \pm 0.22$ & $1.80 \pm 0.70^{*}$ & $4.02 \pm 0.69^{*}$ & $6.14 \pm 1.06^{*}$ & $21.00 \pm 4.33$ \\
$98(\mathrm{n}=10)$ & Ad libitum-fed & $2.24 \pm 0.31^{\mathrm{ab}}$ & $0.69 \pm 0.12^{\mathrm{ab}}$ & $3.12 \pm 0.33^{\mathrm{cd}}$ & $4.14 \pm 0.57^{\mathrm{c}}$ & $16.70 \pm 4.46^{\mathrm{a}}$ \\
$98(\mathrm{n}=10)$ & Overfed & $2.34 \pm 0.22$ & $3.51 \pm 0.96$ & $5.05 \pm 0.58^{*}$ & $6.69 \pm 0.62^{*}$ & $27.94 \pm 4.38^{*}$ \\
\hline \hline
\end{tabular}

${ }^{\mathrm{a}-\mathrm{d}}$ Significant effect of age for ad libitum-fed group between 1 and 98 days of age $(P<0.05)$.

* Significant effect of feeding levels for a given age between 75 and 98 days $(P<0.05)$. 
Lipid deposition in duck muscles

Table 5 Effects of age and feeding levels on lipid, triglyceride, phospholipid and cholesterol levels (mg per $100 \mathrm{~g}$ muscle) in p. major muscle of mule ducks (means \pm s.e.)

\begin{tabular}{|c|c|c|c|c|c|c|}
\hline Age (days) & Feeding levels & Lipids & Triglycerides & Phospholipids & $\begin{array}{l}\text { Esterified } \\
\text { cholesterol }\end{array}$ & Free cholesterol \\
\hline $1(n=1)^{\dagger}$ & Ad libitum-fed & 2930 & 619 & 1468 & 385 & 458 \\
\hline $14(n=2)^{\ddagger}$ & Ad libitum-fed & 2300 & 1140 & 898 & 10.66 & 251 \\
\hline $42(n=20)$ & Ad libitum-fed & $1270 \pm 100^{d}$ & $170 \pm 86^{d}$ & $929 \pm 53^{d}$ & $2.95 \pm 3.86^{\mathrm{a}}$ & $166 \pm 40^{b c}$ \\
\hline $75(n=10)$ & Ad libitum-fed & $2740 \pm 420^{c}$ & $1146 \pm 422^{c}$ & $1225 \pm 159^{c}$ & $1.01 \pm 3.19^{b}$ & $368 \pm 192^{a}$ \\
\hline $75(n=10)$ & Restricted & $2300 \pm 330 *$ & $790 \pm 292^{*}$ & $1190 \pm 187$ & nd & $320 \pm 119$ \\
\hline $84(n=10)$ & Ad libitum-fed & $2830 \pm 350^{b c}$ & $1347 \pm 342^{b c}$ & $1362 \pm 92^{b}$ & nd & $121 \pm 39^{b c}$ \\
\hline $84(n=10)$ & Pre-overfed & $2730 \pm 360$ & $1200 \pm 366$ & $1383 \pm 153$ & nd & $147 \pm 64$ \\
\hline $91(n=10)$ & Ad libitum-fed & $3110 \pm 330^{b}$ & $1569 \pm 248^{b}$ & $1401 \pm 139^{a b}$ & nd & $140 \pm 39^{b c}$ \\
\hline $91(n=10)$ & Overfed & $3490 \pm 510$ & $1919 \pm 389 *$ & $1444 \pm 141$ & nd & $127 \pm 37$ \\
\hline $98(n=10)$ & Ad libitum-fed & $3890 \pm 630^{a}$ & $2263 \pm 537^{a}$ & $1520 \pm 229^{a}$ & nd & $107 \pm 22^{c}$ \\
\hline $98(n=10)$ & Overfed & $5460 \pm 1110^{*}$ & $3622 \pm 923^{*}$ & $1734 \pm 216^{*}$ & nd & $104 \pm 32$ \\
\hline
\end{tabular}

${ }^{\text {a-d }}$ Significant effect of age for ad libitum-fed group between 42 and 98 days $(P<0.05)$; nd $=$ not detected.

* Significant effect of feeding levels for a given age between 75 and 98 days $(P<0.05)$.

$t, \neq$ Analysis performed with a pool of 20 muscles or two pools of 10 muscles, respectively.

The levels of esterified cholesterol in breast muscle, which was maximal at 1 day of age, dropped at 14 days of age (initial value divided by 36). A further decrease occurred until 84 days when it became undetectable (Table 5). At 1 day of age, the free cholesterol levels in breast muscle were high (Table 5), then decreased until 42 days of age (divided by 2.8). We recorded higher levels at 75 days of age, followed by a decrease at 84 days. The levels then remained stable at 84 and 98 days of age. Neither feed restriction nor overfeeding had significant effects on esterified or free cholesterol levels in breast muscle.

The main fatty acids in breast muscle were palmitic (C16:0), stearic (C18:0), oleic (C18:1n-9), linoleic (C18:2n6) and arachidonic (C20:4n-6) acids (Table 6). Saturated, mono-unsaturated and poly-unsaturated fatty acid (SFA, MUFA and PUFA, respectively) levels decreased between 1 and 42 days of age in the ALF group, values being divided by 2.0, 3.0 and 1.7, respectively. Levels then increased regularly until 98 days of age (2.9-fold, 3.6-fold and 2.6-fold for SFA, MUFA and PUFA, respectively). Feed restriction decreased SFA, MUFA and PUFA levels in breast muscle $(-12 \%,-20 \%$ and $-11 \%$, respectively, Table 6$)$ and overfeeding increased only SFA and MUFA levels $(+49 \%$ and $+56 \%$, respectively, at 98 days of age).

\section{Histological characteristics of breast muscle}

The surface occupied by adipocytes on cross-sections of breast muscle was maximal at 1 and 14 days of age then decreased until 75 days of age (value divided by 12.3 between 1 and 75 days, Table 7). It then increased regularly until 98 days of age (6-fold). At 1 and 14 days of age the adipocytes were distributed around the fibre bundles (in the connective tissue) and also inside (between the muscle fibres) while at 98 days of age the adipocytes were mostly distributed around the fibre bundles (in the connective tissue and mainly around the vessels, Figure 1).
In the $P$. major muscle, the average percentages of type $\alpha \mathrm{R}$ and $\alpha \mathrm{W}$ fibres were 81 and $19 \%$, respectively. The cross-sectional area (CSA) of muscle fibres increased with age (96-fold between 1 and 98 days of age in the ALF group, Table 7). The greatest increase in fibre CSA occurred between 14 and 42 days of age (15-fold and 18-fold in $\alpha R$ and $\alpha \mathrm{W}$ fibres, respectively). At 98 days of age, the CSA of $\alpha \mathrm{W}$ fibres was 2.8-fold greater than that of $\alpha \mathrm{R}$ fibres.

The total lipid content of $\alpha R$ fibres increased between 42 and 75 days of age in the ALF group (Table 7). It then remained stable until 98 days of age. The total lipid content of $\alpha \mathrm{W}$ fibres was not affected by age. The triglyceride content of $\alpha R$ fibres increased ( $+51 \%$ ) between 1 and 75 days of age in the ALF group. It then remained stable until 91 days of age before decreasing $(-36 \%)$ significantly between 91 and 98 days of age. The triglyceride content of $\alpha \mathrm{W}$ fibres increased $(+57 \%)$ between 1 and 84 days of age. It then remained stable until 98 days of age.

Neither feed restriction nor overfeeding had a significant effect on the surface occupied by adipocytes, fibre typology (data not shown), fibre CSA or total lipid or triglyceride content in muscle fibres (Table 7).

\section{Enzyme activity}

LDH activity increased steadily in the ALF group between 1 and 91 days of age (8-fold, Table 7). The greatest increase in LDH activity occurred between 14 and 42 days of age (3.4-fold), but between 91 and 98 days of age, it decreased significantly $(-23 \%)$. CS activity increased regularly with age in the ALF group (1.9-fold between 1 and 98 days of age, Table 8). HAD activity remained at low levels between 1 and 42 days of age. It then increased strongly (6.7-fold between 42 and 75 days of age) to remain stable until 98 days of age. In the ALF group, LPL activity was high at 1 and 14 days of age. It decreased considerably at 42 days of age (value divided by 6 between 14 and 42 
Table 6 Effects of age and feeding levels on fatty acid composition ( $\mathrm{g}$ per $100 \mathrm{~g}$ muscle) of total lipids in p. major muscle of ad libitum-fed (ALF) and restricted then overfed (ROF) mule ducks (means \pm s.e. $)^{\dagger}$

\begin{tabular}{|c|c|c|c|c|c|c|c|c|c|c|c|}
\hline \multirow[b]{2}{*}{ Fatty acids } & \multirow[b]{2}{*}{$\begin{array}{c}1 \text { day } \\
(n=1)^{\ddagger}\end{array}$} & \multirow[b]{2}{*}{$\begin{array}{l}14 \text { days } \\
(n=2)^{\S}\end{array}$} & \multirow[b]{2}{*}{$\begin{array}{l}42 \text { days } \\
(n=20)\end{array}$} & \multicolumn{2}{|c|}{75 days } & \multicolumn{2}{|c|}{84 days } & \multicolumn{2}{|c|}{91 days } & \multicolumn{2}{|c|}{98 days } \\
\hline & & & & $\operatorname{ALF}(n=10)$ & $\operatorname{ROF}(n=10)$ & $\operatorname{ALF}(n=10)$ & $\operatorname{ROF}(n=10)$ & $\operatorname{ALF}(n=10)$ & $\operatorname{ROF}(n=10)$ & $\operatorname{ALF}(n=10)$ & $\operatorname{ROF}(n=10)$ \\
\hline $\mathrm{C} 14: 0$ & nd & 0.01 & nd & nd & nd & nd & nd & nd & $0.01 \pm 0.01$ & $0.01 \pm 0.01$ & $0.03 \pm 0.01$ * \\
\hline C16:0 & 0.65 & 0.53 & $0.28 \pm 0.03^{d}$ & $0.61 \pm 0.11^{c}$ & $0.52 \pm 0.08^{*}$ & $0.67 \pm 0.09^{b c}$ & $0.67 \pm 0.09$ & $0.75 \pm 0.09^{b}$ & $0.95 \pm 0.14^{*}$ & $1.00 \pm 0.15^{\mathrm{a}}$ & $1.48 \pm 0.35^{*}$ \\
\hline $\mathrm{C} 17: 0$ & nd & nd & nd & nd & nd & nd & nd & $0.28 \pm 0.88$ & nd & nd & nd \\
\hline C18:0 & 0.33 & 0.24 & $0.21 \pm 0.02^{c}$ & $0.37 \pm 0.04^{\mathrm{ab}}$ & $0.34 \pm 0.04^{*}$ & $0.34 \pm 0.03^{b}$ & $0.33 \pm 0.04$ & $0.34 \pm 0.04^{b}$ & $0.36 \pm 0.05$ & $0.39 \pm 0.05^{\mathrm{a}}$ & $0.58 \pm 0.13^{*}$ \\
\hline$\sum$ SFA & 0.98 & 0.78 & $0.49 \pm 0.04^{c}$ & $0.98 \pm 0.14^{b}$ & $0.86 \pm 0.11^{*}$ & $1.01 \pm 0.12^{b}$ & $1.00 \pm 0.12$ & $1.37 \pm 0.85^{\mathrm{a}}$ & $1.32 \pm 0.19$ & $1.40 \pm 0.18^{a}$ & $2.09 \pm 0.47^{*}$ \\
\hline C15:1 n-5 & 0.09 & 0.05 & $0.07 \pm 0.01^{\mathrm{b}}$ & $0.09 \pm 0.01^{a}$ & $0.08 \pm 0.01$ * & $0.08 \pm 0.01^{a}$ & $0.08 \pm 0.01$ & $0.09 \pm 0.01^{a}$ & $0.08 \pm 0.01$ * & $0.09 \pm 0.01^{\mathrm{a}}$ & $0.08 \pm 0.01$ * \\
\hline C16:1 n-7 & 0.02 & 0.07 & $0.01 \pm 0.01^{d}$ & $0.05 \pm 0.02^{c}$ & $0.04 \pm 0.01$ & $0.06 \pm 0.02^{b c}$ & $0.06 \pm 0.02$ & $0.07 \pm 0.02^{b}$ & $0.12 \pm 0.03 *$ & $0.10 \pm 0.02^{a}$ & $0.17 \pm 0.05^{*}$ \\
\hline C17:1 n-7 & 0.05 & 0.02 & 0.02 & 0.03 & 0.03 & $0.03 \pm 0.01$ & $0.03 \pm 0.01$ & 0.03 & $0.02 \pm 0.01$ & $0.02 \pm 0.02$ & $0.03 \pm 0.03$ \\
\hline C18:1 n-9 & 1.21 & 0.96 & $0.35 \pm 0.06^{\mathrm{d}}$ & $0.86 \pm 0.22^{c}$ & $0.68 \pm 0.14^{*}$ & $0.93 \pm 0.17^{b c}$ & $0.85 \pm 0.16$ & $1.06 \pm 0.18^{b}$ & $1.26 \pm 0.22 *$ & $1.42 \pm 0.33^{\mathrm{a}}$ & $2.26 \pm 0.53^{*}$ \\
\hline C20:1 n-9 & nd & 0.02 & nd & nd & nd & nd & nd & nd & nd & nd & nd \\
\hline$\Sigma$ MUFA & 1.37 & 1.12 & $0.45 \pm 0.05^{d}$ & $1.03 \pm 0.23^{c}$ & $0.83 \pm 0.15^{*}$ & $1.10 \pm 0.18^{b c}$ & $1.02 \pm 0.16$ & $1.25 \pm 0.19^{b}$ & $1.48 \pm 0.16$ & $1.63 \pm 0.35^{\mathrm{a}}$ & $2.54 \pm 0.57^{*}$ \\
\hline C18:2 n-6 & 0.22 & 0.30 & $0.17 \pm 0.02^{d}$ & $0.46 \pm 0.06^{\mathrm{c}}$ & $0.39 \pm 0.06^{*}$ & $0.47 \pm 0.06^{b c}$ & $0.47 \pm 0.08$ & $0.52 \pm 0.05^{b}$ & $0.47 \pm 0.06$ & $0.61 \pm 0.09^{\mathrm{a}}$ & $0.62 \pm 0.13$ \\
\hline$C 20: 4$ n- 6 & 0.35 & 0.10 & $0.16 \pm 0.03^{c}$ & $0.27 \pm 0.02^{\mathrm{a}}$ & $0.23 \pm 0.04^{*}$ & $0.25 \pm 0.04^{\mathrm{a}}$ & $0.25 \pm 0.04$ & $0.25 \pm 0.04^{\mathrm{a}}$ & $0.22 \pm 0.04$ & $0.25 \pm 0.04^{\mathrm{a}}$ & $0.21 \pm 0.03^{*}$ \\
\hline$\Sigma$ PUFA & 0.57 & 0.40 & $0.33 \pm 0.03^{c}$ & $0.73 \pm 0.07^{b}$ & $0.62 \pm 0.09 *$ & $0.72 \pm 0.08^{b}$ & $0.72 \pm 0.11$ & $0.76 \pm 0.07^{b}$ & $0.69 \pm 0.10$ & $0.86 \pm 0.12^{\mathrm{a}}$ & $0.83 \pm 0.15$ \\
\hline UFA / SFA & 1.98 & 1.94 & $1.60 \pm 0.08^{b}$ & $1.79 \pm 0.08^{\mathrm{a}}$ & $1.69 \pm 0.09^{*}$ & $1.79 \pm 0.13^{\mathrm{a}}$ & $1.73 \pm 0.13$ & $1.68 \pm 0.42^{\mathrm{ab}}$ & $1.65 \pm 0.06$ & $1.77 \pm 0.14^{\mathrm{ab}}$ & $163 \pm 0.19$ \\
\hline PUFA/SFA & 0.58 & 0.51 & $0.67 \pm 0.06^{b}$ & $0.75 \pm 0.06^{\mathrm{a}}$ & $0.73 \pm 0.06$ & $0.71 \pm 0.05^{\mathrm{ab}}$ & $0.72 \pm 0.07$ & $0.64 \pm 0.16^{b}$ & $0.52 \pm 0.04^{*}$ & $0.62 \pm 0.05^{b}$ & $0.41 \pm 0.05^{*}$ \\
\hline
\end{tabular}

${ }^{\text {a-d }}$ Significant effect of age for ad libitum-fed group between 42 and 98 days $(P<0.05)$; nd $=$ not detected.

Significant effect of feeding levels for a given age between 75 and 98 days, $(P<0.05)$.

$\$, \$$ Analysis performed with a pool of 20 muscles or two pools of 10 muscles, respectively. 
Lipid deposition in duck muscles

Table 7 Effects of age and feeding levels on the relative surface occupied by adipocytes on cross-sections of muscle, cross-sectional area (CSA) of fibres and luminance due to the presence of triglycerides (LC RO) or total lipids (LC SB) in fibres of p. major muscle of mule ducks (means \pm s.e. $)^{\dagger}$

\begin{tabular}{|c|c|c|c|c|c|c|c|c|}
\hline \multirow[b]{2}{*}{ Age (days) } & \multirow[b]{2}{*}{ Feeding levels } & \multicolumn{2}{|c|}{ Adipocyte } & \multicolumn{3}{|c|}{ Fibres $\alpha \mathrm{R}$} & \multicolumn{2}{|c|}{ Fibres $\alpha \mathrm{W}$} \\
\hline & & Surface (\%) & $\mathrm{CSA}(\mu \mathrm{m} 2)$ & LC SB & Lc RO & $\mathrm{CSA}(\mu \mathrm{m} 2)$ & LC SB & Lc RO \\
\hline $1(n=20)$ & Ad libitum-fed & $2.71 \pm 1.16^{\mathrm{a}}$ & $8 \pm 3^{c}$ & $123 \pm 26^{a}$ & $137 \pm 27^{\mathrm{a}}$ & $12 \pm 5^{d}$ & $124 \pm 28^{\mathrm{a}}$ & $143 \pm 29^{a}$ \\
\hline $14(n=20)$ & Ad libitum-fed & $2.11 \pm 1.48^{\mathrm{a}}$ & $14 \pm 3^{c}$ & $114 \pm 9^{a}$ & $96 \pm 25^{b}$ & $30 \pm 12^{d}$ & $120 \pm 7^{\mathrm{a}}$ & $99 \pm 12^{b}$ \\
\hline $42(n=20)$ & Ad libitum-fed & $0.54 \pm 0.59^{c}$ & $212 \pm 74^{b}$ & $110 \pm 15^{a}$ & $87 \pm 23^{b}$ & $550 \pm 248^{c}$ & $128 \pm 16^{\mathrm{a}}$ & $93 \pm 23^{b}$ \\
\hline $75(n=10)$ & Ad libitum-fed & $0.22 \pm 0.17^{c}$ & $625 \pm 93^{\mathrm{ab}}$ & $79 \pm 28^{b}$ & $67 \pm 23^{c}$ & $1561 \pm 343^{b}$ & $120 \pm 21^{\mathrm{a}}$ & $77 \pm 19^{b c}$ \\
\hline $75(n=10)$ & Restricted & $0.22 \pm 0.09$ & $620 \pm 81$ & $77 \pm 30$ & $65 \pm 18$ & $1397 \pm 412$ & $125 \pm 20$ & $76 \pm 12$ \\
\hline $84(n=10)$ & Ad libitum-fed & $0.39 \pm 0.28^{c}$ & $659 \pm 186^{a b}$ & $75 \pm 21^{b}$ & $62 \pm 12^{c}$ & $1525 \pm 525^{b}$ & $78 \pm 19^{b}$ & $62 \pm 6^{c}$ \\
\hline $84(n=10)$ & Pre-overfed & $0.35 \pm 0.30$ & $691 \pm 128$ & $76 \pm 27$ & $59 \pm 6$ & $1455 \pm 222$ & $87 \pm 19$ & $61 \pm 11$ \\
\hline $91(n=10)$ & Ad libitum-fed & $1.02 \pm 0.38^{b c}$ & $682 \pm 84^{\mathrm{a}}$ & $75 \pm 13^{b}$ & $61 \pm 7^{c}$ & $1678 \pm 502^{b}$ & $107 \pm 17^{\mathrm{a}}$ & $71 \pm 7^{\mathrm{bc}}$ \\
\hline $91(n=10)$ & Overfed & $0.87 \pm 0.36$ & $677 \pm 131$ & $72 \pm 28$ & $65 \pm 19$ & $1637 \pm 618$ & $116 \pm 32$ & $77 \pm 25$ \\
\hline $98(n=10)$ & Ad libitum-fed & $1.33 \pm 0.40^{b}$ & $767 \pm 105^{a}$ & $90 \pm 28^{b}$ & $83 \pm 25^{b}$ & $2143 \pm 636^{a}$ & $101 \pm 44^{\mathrm{ab}}$ & $88 \pm 31^{b c}$ \\
\hline $98(n=10)$ & Overfed & $1.96 \pm 1.08$ & $758 \pm 146$ & $87 \pm 20$ & $77 \pm 20$ & $1777 \pm 670$ & $94 \pm 31$ & $80 \pm 25$ \\
\hline
\end{tabular}

${ }_{*}^{\text {a-c }}$ Significant effect of age for ad libitum-fed group between 1 and 98 days $(P<0.05)$.

* Significant effect of feeding levels for a given age between 75 and 98 days $(P<0.05)$.

${ }^{\dagger} \alpha \mathrm{R}$ and $\alpha \mathrm{W}$ fibres: oxydo-glycolytic and glycolytic fast-twitch fibres, respectively. Luminance was negatively correlated with lipid levels.

days), increased significantly at 75 days of age $(2.5$-fold $)$ to remain stable until 98 days of age (Table 8).

Feed restriction had no significant effect on LDH, CS, HAD or LPL activity. Overfeeding decreased LDH activity, particularly during the 2 nd week $(-22 \%$ at 98 days of age), and increased LPL activity, particularly during the 1st week (2.3-fold and 1.8-fold at 91 and 98 days of age, respectively, Table 8). It had no significant effect on CS or HAD activity.

Correlations between LPL activity and lipid levels in breast muscle, or phospholipid, triglyceride and cholesterol levels in plasma were the following: $+0.33(P<0.01),+0.45$ $(P<0.01),+0.13(P>0.05)$ and $+0.51 \quad(P<0.001)$, respectively.

\section{Discussion}

\section{Age effects}

The kinetics of fat deposition in the breast muscle might be divided into two periods, i.e. before and after 42 days of age, the greatest effects of age occurring between 14 and 42 days when the growth of the breast muscle was maximal (weight increased 27-fold, CSA increased 15 and 18-fold in $\alpha \mathrm{R}$ and $\alpha \mathrm{W}$ fibre types, respectively). The energy metabolism of birds is based on the use of lipids stored in egg yolk until hatching (Noble and Cocchi, 1990; Klasing, 1998). Total lipid content in the breast muscle of mule ducks was therefore high at 1 day of age $(2.9 \mathrm{~g}$ per $100 \mathrm{~g}$ of muscle) and mainly composed of phospholipids (50\% of total lipids) and cholesterol (29\%), reflecting the high phospholipid and cholesterol plasma levels. They are transferred from the egg yolk to the liver during embryonic development (Noble and Cocchi, 1990; Klasing, 1998). Egg yolk is rich in oleic acid (C18:1n-9), which represents $33 \%$ of the total fatty acids (Noble and Cocchi, 1990; Lin and Yang, 2000). This may explain the high oleic acid levels measured in the breast muscle of mule ducks at 1 day of age ( $41 \%$ of total fatty acids). LPL activity was high at 1 and 14 days of age, allowing breast muscle to import blood lipids. Lipids were mainly stored in adipocytes in the breast muscle of 1-day-old ducklings which could be
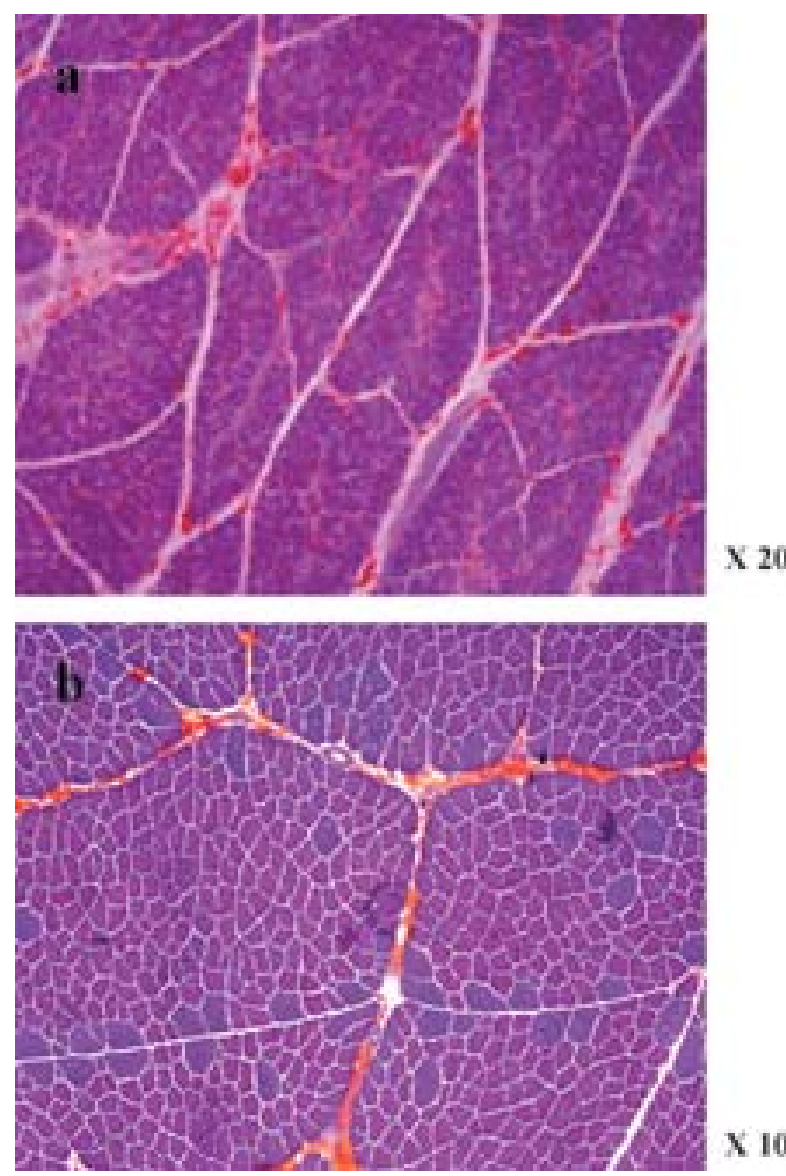

Figure 1 Cross sections of pectoralis major muscle stained with red oil and purple crystal to put in evidence intramuscular adipocytes and fibres, respectively, from mule ducks at (a) 1 day and (b) 98 days of age. 
Chartrin, Bernadet, Guy, Mourot, Hocquette, Rideau, Duclos and Baéza

Table 8 Effects of age and feeding levels on enzyme activity (IU/g of muscle) of lactate dehydrogenase (LDH), citrate synthase (CS), $\beta$-hydoxyacyl-CoA dehydrogenase (HAD) and lipoprotein lipase (LPL expressed as nmol/min per g muscle) in p. major muscle of mule ducks (means \pm s.e.)

\begin{tabular}{llcccc}
\hline \hline Age (days) & Feeding levels & \multicolumn{1}{c}{ LDH } & CS & HAD & LPL \\
\hline $1(n=20)$ & Ad libitum-fed & $86.67 \pm 111.83^{\mathrm{f}}$ & $6.63 \pm 1.76^{\mathrm{d}}$ & $2.49 \pm 0.86^{\mathrm{c}}$ & $565 \pm 167^{\mathrm{a}}$ \\
$14(\mathrm{n}=20)$ & Ad libitum-fed & $135.27 \pm 24.47^{\mathrm{e}}$ & $5.72 \pm 0.93^{\mathrm{d}}$ & $3.20 \pm 4.67^{\mathrm{c}}$ & $573 \pm 264^{\mathrm{a}}$ \\
$42(\mathrm{n}=20)$ & Ad libitum-fed & $459.53 \pm 77.56^{\mathrm{d}}$ & $9.45 \pm 1.24^{\mathrm{c}}$ & $2.21 \pm 0.33^{\mathrm{c}}$ & $93 \pm 34^{\mathrm{c}}$ \\
$75(\mathrm{n}=10)$ & Ad libitum-fed & $587.55 \pm 78.57^{\mathrm{b}}$ & $10.75 \pm 2.50^{\mathrm{bc}}$ & $14.78 \pm 6.86^{\mathrm{a}}$ & $236 \pm 62^{\mathrm{b}}$ \\
$75(\mathrm{n}=10)$ & Restricted & $601.27 \pm 55.26$ & $11.74 \pm 3.23$ & $13.48 \pm 3.67$ & $175 \pm 96$ \\
$84(\mathrm{n}=10)$ & Ad libitum-fed & $568.50 \pm 68.36^{\mathrm{b}}$ & $11.68 \pm 2.43^{\mathrm{ab}}$ & $11.75 \pm 3.87^{\mathrm{ab}}$ & $190 \pm 88^{\mathrm{bc}}$ \\
$84(\mathrm{n}=10)$ & Pre-overfed & $575.57 \pm 69.49$ & $10.52 \pm 2.81$ & $10.32 \pm 3.32$ & $233 \pm 168$ \\
$91(\mathrm{n}=10)$ & Ad libitum-fed & $695.61 \pm 122.54^{\mathrm{a}}$ & $12.48 \pm 2.78^{\mathrm{ab}}$ & $12.22 \pm 5.41^{\mathrm{ab}}$ & $201 \pm 40^{\mathrm{bc}}$ \\
$91(\mathrm{n}=10)$ & Overfed & $635.08 \pm 73.18$ & $12.69 \pm 2.72$ & $10.39 \pm 3.94$ & $468 \pm 168^{*}$ \\
$98(\mathrm{n}=10)$ & Ad libitum-fed & $534.87 \pm 67.00^{\mathrm{c}}$ & $12.75 \pm 2.39^{\mathrm{a}}$ & $9.85 \pm 3.35^{\mathrm{b}}$ & $160 \pm 58^{\mathrm{bc}}$ \\
$98(\mathrm{n}=10)$ & Overfed & $419.76 \pm 65.15^{*}$ & $11.68 \pm 2.22$ & $10.73 \pm 1.86$ & $295 \pm 97^{*}$ \\
\hline \hline
\end{tabular}

a-f Significant effect of age for ad libitum-fed group between 1 and 98 days $(P<0.05)$.

"Significant effect of feeding levels for a given age between 75 and 98 days $(P<0.05)$.

a specificity of birds as in most mammals, where triglycerides are mainly stored in the fibre cytoplasm at birth and adipocytes develop later (Hauser et al., 1997; Gondret et al., 1998). By contrast, total lipid and triglyceride levels in muscle fibres were lower at hatching than at older ages. Breast muscle development occurred mainly after 14 days of age. The levels of enzyme activity reflecting energy metabolism (CS, HAD, LDH) were therefore low at hatching as previously reported in mammals.

We observed a decrease in total lipid content in the breast muscle of mule ducks induced mainly by a decrease in phospholipids and cholesterol between 1 and 42 days of age. In terms of fatty acid composition, the greatest decrease was in oleic acid. Lin and Yang (2000) also observed a decrease in oleic acid in the hearts of mule ducks between 1 and 21 days of age. The total lipid content in muscles is unchanged or decreased in turkeys and chickens, respectively, during the first few weeks of post-hatch development (Touraille et al., 1981; Hamm and Ang, 1984; Rabot, 1998). Triglyceride content in fibres increased in breast muscle of mule ducks at day 14 whereas the surface occupied by adipocytes decreased at day 42 . Since CS and HAD activity increased, it can be hypothesised that muscle fibres use the lipids stored in adipocytes to supply their energy requirements for growth. The LPL activity of breast muscle decreased, in agreement with the decrease in LPL activity in adipose tissues of Aylesbury ducks (Anas platyrhynchos) reported by Evans (1972). It seems that LPL activity in breast muscle depends on plasma levels of lipids.

We observed an increase in total lipid content in the breast muscle of mule ducks, induced by an increase mainly in triglycerides, but also in phospholipids, between 42 and 98 days of age. At 98 days of age, triglycerides represented $58 \%$ of total lipids. Setiawan et al. (1994) and Baéza et al. (2000) and (2002) also reported an increase in total lipid content in the breast muscle of mule ducks between 42 or 56 and 91 days of age and in the breast muscle of Muscovy ducks between 56 and 84 days of age, respectively. In the present study, analysis of fatty acid composition showed that the main increase involved MUFA (particularly oleic acid) and SFA (particularly palmitic acid) provided by lipogenesis in the liver (Klasing, 1998) or feed. During this second period, lipids were first stored in muscle fibres: the triglyceride content increased until 75 and 84 days of age in $\alpha R$ and $\alpha \mathrm{W}$ fibre types, respectively. Later, lipids were stored in adipocytes which occupied an increasing surface from 75 days of age. This was consistent with a study involving rabbit muscles: in this species, the age-related increase in total muscle lipid and triglyceride contents was closely associated with the increase in numbers and size of clustered adipocytes (Gondret et al., 1998). LPL activity increased in the breast muscle of mule ducks between 42 and 75 days of age allowing an increased uptake of circulating lipids, then remained stable. HAD, LDH and CS activity increased until 75, 91 and 98 days of age, respectively. LDH activity was much higher than CS and HAD activity. These findings were in agreement with previous reports in Muscovy ducks by Baéza et al. (1998) and confirm that oxidative metabolism is prevalent in breast muscle at the beginning of postnatal development whereas glycolytic metabolism takes over in later development, as reported by Bacou and Vigneron (1976) in chicks and Briand et al. (1993) in rabbits. Plasma levels of glucose, insulin and triglycerides, measured following $12 \mathrm{~h}$ fasting, remained almost stable during the whole experimental period. Vasilatos-Younken (1986) and McMurtry et al. (1988) reported decreases in plasma insulin with age in chickens from 28 to 84 days and from 6 to 54 days, respectively. In these studies, blood samples were drawn 6 or $2 \mathrm{~h}$ after a meal, respectively, which might explain the significant age effect on plasma insulin level.

Feed restriction effects between 75 and 84 days of age Feed restriction corresponded to $79 \%$ of ad libitum ingestion between 43 and 75 days of age, but it did not alter body weight or breast muscle weight. It improved feed efficiency (feed conversion ratios were 6.44 and 9.55 for 
ROF and ALF groups, respectively), probably by reducing carcass fattiness and muscle lipid levels. McMurtry et al. (1988) found no effect of feed restriction on plasma insulin levels in chickens but in this study feed restriction was shorter ( 6 days) and occurred earlier (from 6 to 12 days of age). In our study, despite the decrease in plasma insulin levels induced by feed restriction, glycaemia, plasma triglyceride, phospholipid and total cholesterol levels and LPL activity in the breast muscle were not affected. The reduced plasma insulin levels probably reduced liver lipogenic activity and the amounts of neo-synthesised lipids exported to peripheral tissues such as muscle and adipose tissues, as previously reported by Tan et al. (1999) and Tan and Ohtani (2000). Since feed restriction was moderate and applied after maximal growth of the breast muscle, the decrease in total lipid content of the breast muscle was therefore moderate $(-16 \%)$ and mainly affected triglyceride $(-31 \%)$ and MUFA $(-20 \%)$ levels. It had no significant influence on the energy metabolism of the breast muscle, the surface occupied by adipocytes, fibre type, CSA and total lipid and triglyceride contents. Restricted feed intake during fattening in rabbits has also been reported to reduce intramuscular lipid deposition without modifying muscle fibre characteristics (Gondret et al., 2000).

\section{Overfeeding effects}

Kinetic studies during the overfeeding period have only reported findings on lipid deposition in duck livers (Baudonnet-Lenfant, 1993; Auvergne et al., 1995; Robin et al., 2002 and 2004). Studies concerning lipid deposition in muscles have only compared pre-overfed $v$. overfed ducks slaughtered at different ages (Auvergne, 1992; Hermier et al., 2003) and ad libitum-fed v. overfed ducks slaughtered at the same age (Zanusso et al., 2003; Chartrin et al., 2005 and 2006). In the present study, we compared ad libitum-fed and overfed ducks at three different stages, i.e. the beginning, middle and end of the overfeeding period. The main effects of overfeeding occurred during the 2 nd week of this period. Overfeeding resulted in a considerable increase in body weight. Previous studies have shown that it resulted from a dramatic increase in the synthesis of lipids in the liver leading to fatty liver formation and to lipid export to peripheral tissues such as adipose tissues and muscles (Guy et al., 1999; Hermier et al., 2003). Plasma triglyceride, phospholipid and total cholesterol levels therefore increased. Glycaemia measured $12 \mathrm{~h}$ after a meal was not affected by overfeeding, suggesting that the relative hyperinsulinaemia observed in overfed ducks was sufficient for normalisation of glycaemia and that overfed ducks do not become insulin resistant. LPL activity in the breast muscle was increased mainly during the first week and it could be hypothesised that this results from hyperinsulinaemia. The increase was less during the 2nd week. It is generally accepted that overfeeding leading to obesity in mammals increases LPL activity (Granneman and Wade, 1983; Dugail et al., 1986; Cleary and Phillips, 1996). Davail et al. (2003) measured plasma LPL activity in mule ducks 90 min after a meal, on the 1st and 10th days of overfeeding. They reported a considerable decrease in plasma LPL activity at the 10th day of overfeeding $(1.17 \mathrm{v}$. $4.12 \mu \mathrm{mol}$ palmitate per $\mathrm{h}$ per $\mathrm{ml}$ ). This down regulation of LPL activity during the 2nd week of overfeeding needs further investigation.

As previously reported by Zanusso et al. (2003) in Muscovy ducks, and Chartrin et al. (2006) in Muscovy and Pekin ducks and their hybrids, hinny and mule ducks, total lipid levels in the breast muscle increased. This was mainly due to increases in triglyceride and MUFA levels, and to a lesser extent to increases in phospholipid and SFA levels. Overfeeding did not affect the fibre type or CSA of breast muscle fibres. The decrease in the luminance values for red oil and Sudan black staining, indicating increased triglyceride and total lipid levels in muscle fibres and the increase in the surface occupied by adipocytes, were not significant. We did not confirm the results of a previous study in which Chartrin et al. (2005) reported that overfeeding significantly increased the triglyceride content of $\alpha \mathrm{R}$ fibres and the surface occupied by adipocytes in breast muscle compared with ad libitum-fed ducks. In the latter study, the number of repetitions per treatment was 32 and the increase in total lipid content of breast muscle from mule ducks was also greater than in the present experiment (1.7-fold v. 1.4-fold). Nevertheless, the glycolytic metabolism of breast muscle in the present study was affected by overfeeding, since LDH activity was significantly decreased at 98 days of age. Zanusso et al. (2003) found no significant effect of overfeeding on LDH activity in Muscovy ducks, but there was an increase in CS and HAD activity. It seems more relevant to consider the CS/LDH or HAD/LDH ratios. When they increase, the use of fatty acids for energy metabolism is enhanced.

Breast muscle weight decreased during the 1st week of overfeeding. It can be hypothesised that muscle proteolysis increased to provide amino acids to the liver for protein synthesis (hyperplasia and hypertrophy of hepatocytes, lipopoprotein synthesis). At the end of the overfeeding period, the muscle had recovered its initial weight.

\section{Conclusion}

The original contribution of this study was to describe the kinetics of lipid deposition in relation to its localisation (adipocytes and muscle fibres) in the breast muscle of ducks during growth post-hatch. This has not been reported for any domesticated bird to date. Two periods can be defined for age effects on intramuscular lipids in breast muscle: -1 to 42 days of age when lipids stored in the adipocytes during embryonic life are used by the muscle fibres for growth and energy requirements, and -42 to 98 days of age when the muscle again stores lipids, first in fibres then in adipocytes.

Feed restriction, corresponding to $79 \%$ of ad libitum ingestion, applied between 42 and 75 days of age only resulted in 
a slight decrease in total lipid content of the breast muscle, mainly involving triglyceride and MUFA levels. Overfeeding considerably increased total lipid levels in the breast muscle, mainly due to triglyceride and MUFA deposition occurring particularly during the 2 nd week of this period. As found by Gondret et al. (2000) in rabbits, we observed that nutritional status regulates intramuscular lipid deposition in ducks without changing fibre-type composition.

During the first weeks of post-hatch development, the increase in HAD, CS and LDH activity depends on muscle development. After 91 days of age, LDH activity can be decreased by age or overfeeding leading to an increase in muscle lipid levels.

The LPL activity seems to be regulated by the plasma lipid levels. It is high when lipids circulate at high concentrations in plasma leading to increases in muscle lipid levels as observed during the first 2 weeks of post-hatch development and during overfeeding.

\section{Acknowledgements}

We thank the technical staff of INRA Artiguères for rearing and overfeeding ducks, Thierry Bordeau for his expert technical assistance in animal dissection and sample preparation and D. Chadeyron and N. Guivier of INRA Theix for their expertise in measurement of enzyme activities. We are grateful to Daniel Tanguy for improving the use of Racine software by modifying the Unix environment to the Windows environment.

\section{References}

Auvergne A Facteurs de variation de la composition corporelle et tissulaire des canards avant et après gavage. Ph.D. thesis, INP Toulouse, France.

Auvergne A, Rémignon H, Babilé R and Baudonnet-Lenfant C 1995. Evolution corporelle au cours du gavage chez le canard de Barbarie. Archiv für Geflügelkunde 59, 234-240.

Bacou F and Vigneron P 1976. Evolution péri-natale des voies métaboliques glycolytiques et oxydatives de divers types de muscles squelettiques du lapin et du poulet. Annals of Biology and Animal Biochemistry 16, 675-685.

Baéza E, Dessay C, Wacrenier N, Marché G and Listrat A 2002. Effect of selection for improved body weight and composition on muscle and meat characteristics in Muscovy ducks. British Poultry Science 43, 560-568.

Baéza $E$, Marche $G$ and Wacrenier N 1999. Effect of sex on muscular development of Muscovy ducks. Reproduction Nutrition Development 39, 675-682.

Baéza E, Rideau N, Chartrin P, Davail S, Hoo-Paris R, Mourot J, Guy G, Bernadet MD, Juin H, Meteau K and Hermier D 2005. Canards de Barbarie, Pékin et leurs hybrides: aptitude à l'engraissement. INRA Productions Animales 18, 131-141.

Baéza E, Salichon MR, Marché G and Juin H 1998. Effect of sex on growth, technological and organoleptic characteristics of the Muscovy duck breast muscle. British Poultry Science 39, 398-403.

Baéza E, Salichon MR, Marché G, Wacrenier N, Dominguez B and Culioli J 2000. Effects of age and sex on the structural, chemical and technological characteristics of mule duck meat. British Poultry Science 41, 300-307.

Bass A, Brdiczka D, Eyer P, Hoper P and Pette D 1969. Metabolic differentiation of distinct muscle types at the level of enzymatic organization. European Journal of Biochemistry 10, 198-206.

Baudonnet-Lenfant C, (1993) Facteurs de variation de la composition biochimique et de la qualité technologique des foies gras de canards. Ph.D. thesis, INP, Toulouse, France.

Briand M, Boissonet G, Laplace-Marieze V and Briand Y 1993. Metabolic and contractile differentiation of rabbit muscles during growth. International Journal of Biochemistry 25, 1881-1887.
Chartrin P, Bernadet MD, Guy G, Mourot J, Duclos MJ and Baéza E 2005. Effects of genotype and overfeeding lipid deposition in myofibres and intramuscular adipocytes of breast and thigh muscles of ducks. Reproduction Nutrition Development 45, 87-99.

Chartrin P, Bernadet MD, Guy G, Mourot J, Duclos MJ and Baéza E 2006. Effects of genotype and overfeeding on fat content of adipose and muscle tissues in ducks. Animal Research 55, 231-244.

Cleary MP and Phillips FC 1996. Metabolic comparisons of 10-week-old obese ( $\mathrm{fa} / \mathrm{fa}$ ) Zucker rats with both heterozygous (Fa/fa) and homozygous (FA/FA) lean rats. Nutrition Research 16, 1341-1352.

Davail S, Rideau N, Guy G, André JM, Hermier D and Hoo-Paris R 2003. Hormonal and metabolic responses to overfeeding in three genotypes of ducks. Comparative Biochemistry and Physiology Part A 134, 707-715.

Dugail I, Quignard-Boulange A and Dupuy F 1986. Role of adipocyte precursors in the onset of obesity induced by overfeeding in suckling rats. Journal of Nutrition 116, 524-535.

Evans AJ 1972. Lipoprotein lipase activity in adipose tissue of the domestic duck: the effect of age, sex and nutritional state. International Journal of Biochemistry 3, 199-206.

Folch J, Lees M and Sloane Stanley GH 1957. A simple method for the isolation and purification of total lipids from animal tissues. Journal of Biological Chemistry 226, 497-509.

Fossati P and Prencipe L 1982. Serum triglycerides determined colorimetrically with an enzyme that produces hydrogen peroxide. Clinical Chemistry 28, 2077-2080.

Gondret F, Lebas F and Bonneau M 2000. Restricted feed intake during fattening reduces intramuscular lipid deposition without modifying muscle fiber characteristics. Journal of Nutrition 130, 228-233.

Gondret F, Mourot J and Bonneau M 1998. Comparison of intramuscular adipose tissue cellularity in muscles differing in their lipid content and fibre type composition during rabbit growth. Livestock Production Science 54, 1-10.

Granneman JG and Wade GN 1983. Effect of sucrose overfeeding on brown adipose tissue lipogenesis and lipoprotein lipase activity in rats. Metabolism 32, 202-207.

Grey TC, Robinson D, Jones JM, Stock SW and Thomas NL 1983. Effect of age and sex on the composition of muscle and skin from a commercial broiler strain. British Poultry Science 24, 219-231.

Guy G, Hermier D, Davail S, Bely M, André JM and Hoo-Paris R 1999. Meat production and force feeding ability of different types of ducks. In Proceedings, 1st World Waterfowl Conference. 1-4/12/99, Taichung, Taïwan, pp. 462-468.

Hamm D and Ang CYW 1984. Effect of sex and age on proximate analysis, cholesterol and selected vitamins in broiler breast meat. Journal of Food Science 49, 286-287.

Hauser N, Mourot J, De Clercq L, Genart C and Remacle C 1997. The cellularity of developing adipose tissues in Pietrain and Meishan pigs. Reproduction Nutrition Development 37, 617-625.

Hermier D, Guy G, Guillaumin S, Davail S, André JM and Hoo-Paris R 2003. Differential channelling of liver lipids in relation to susceptibility to hepatic steatosis in two species of ducks. Comparative Biochemistry and Physiology Part B 135, 663-675.

Hocquette JF, Graulet B and Olivecrona T 1998b. Lipoprotein lipase activity and mRNA levels in bovine tissues. Comparative Biochemistry and Physiology Part B 121, 201-212.

Hocquette JF, Ortigues-Marty I, Pethick DW, Herpin P and Fernandez X 1998a. Nutritional and hormonal regulation of energy metabolism in skeletal muscles of meat-producing animals. Livestock Production Science 56, 115-143.

Kadish AH, Little RL and Sternberg JC 1968. A new rapid method for the determination of glucose by measurement of rate of oxygen consumption. Clinical Chemistry 14, 116-131.

Klasing KC 1998. Lipids. In Comparative avian nutrition (ed. CK Klasing), pp. 171-200. CAB International, Davis, USA.

Komprda T, Sarmanova I, Zelenka J, Bakaj P, Fialova M and Fajmonova E 2002. Effect of sex and age on cholesterol and fatty acid content in turkey meat. Archiv für Geflügelkunde 66, 263-273.

Lin MF and Yang CP 2000. Growth performance, plasma lipids and fatty acid composition of tissue lipids in growing mule ducklings. Food Science and Agricultural Chemistry 2, 101-106.

McMurtry JP, Plavnik I, Rosebrough RW, Steele NC and Proudman JA 1988. Effect of early feed restriction in male broiler chicks on plasma metabolic 
hormones during feed restriction and accelerated growth. Comparative Biochemistry and Physiology A 91, 67-70.

Mares P, Ranny M, Sedlacek J and Skorepa J 1983. Chromatography analysis of blood lipids. Comparison between gas chromatography and thin layer chromatography with flame ionisation detector. Journal of Chromatography 277, 295-305.

Marion JE and Miller WO 1968. Phospholipids and component fatty acids of chicken tissues. Poultry Science 47, 1453-1459.

Morrisson WR and Smith ML 1964. Preparation of fatty acid methyl esters and dimethylacetates from lipid with boron trifluoride methanol. Journal of Lipid Research 5, 600-608.

Noble RC and Cocchi M 1990. Lipid metabolism and the neonatal chicken. Progress in Lipid Research 29, 107-140.

Rabot C 1998. Vitesse de croissance et caractéristiques lipidiques et sensorielles des muscles de poulet. Ph.D. thesis, INA PG, Paris, France.

Richmond W 1973. Preparation and properties of a cholesterol oxydase from Nocardia sp. and its application to the enzymatic assay of total cholesterol in serum. Clinical Chemistry 19, 93-98.

Robin, N, Larroudé, P, Peyhorgue, A and Castaing, J 2002. Evolution du foie gras de canard mulard au cours du gavage en relation avec différents itinéraires techniques. Proceedings, 5èmes Journées de la Recherche sur les Palmipèdes à Foie Gras, Arcachon, France, 9-10 October, pp. 152-155

Robin, N, Peyhorgue, A and Bénard, G 2004. Caractérisation des foies gras de canards mulards en relation avec la durée de gavage. Proceedings, 6èmes Journées de la Recherche sur les Palmipèdes à Foie Gras, Arcachon, France, 7-8 October, pp. 195-198

Statistical Analysis Systems Institute 1989. In SAS/STAT user's guide. SAS Institute Inc., Cary, NC.
Setiawan I, Babilé R, Auvergne A, Belveze S and Latil G 1994. Croissance et composition corporelle de 2 types génétiques de canards mulards. Annales de Zootechnie 43, 185-196.

Simon J, Freychet P and Rosselin G 1974. Chicken insulin: radioimmunological characterization and enhanced activity in rat fat cells and liver plasma membranes. Endocrinology 95, 1439-1449.

Takayama M, Itoh S, Nagasaki T and Tanimizu I 1977. A new enzymatic method for determination of serum choline-containing phospholipids. Clinical Chemistry Acta 79, 1350-1355.

Tan BJ and Ohtani S 2000. Effect of different early feed restriction regimens on performance, carcass composition and lipid metabolism in male ducks. Animal Science Journal 71, 586-593.

Tan BJ, Ohtani S and Tanaka KI 1999. Effect of early feed restriction of varied severity on growth performance, carcass composition and lipid metabolism in female ducks. Animal Science Journal 70, 297-305.

Touraille C, Ricard FH, Kopp J, Valin C and Leclercq B 1981. Qualité du poulet. 2- évolution en fonction de l'âge des caractéristiques physicochimiques et organoleptiques de la viande. Archiv für Geflügelkunde 45, 97-104.

Vasilatos-Younken R 1986. Age-related changes in tissue metabolic rates and sensitivity to insulin in the chicken. Poultry Science 65, 1391-1399.

Wangen RM, Marion WW and Hotchkiss DK 1972. Influence of age on the fatty acid composition of breast and thigh muscles of male turkeys. Agricultural Biology Chemistry 36, 2081-2086.

Zanusso J, Rémignon H, Guy G, Manse $\mathrm{H}$ and Babilé R 2003. The effects of overfeeding on myofibre characteristics and metabolical traits of the breast muscle in Muscovy ducks (Cairina moschata). Reproduction Nutrition and Development 43, 105-115. 